\title{
SENI KRIYA KAYU KINETIK KUMBANG TANDUK
}

\author{
Dedy Shofianto *)
}

\begin{abstract}
This Final Project's artworks were inspired from author's daily and hobby, it is Gothic Lolita that created into artwear. Lolita itself is one of fashion sub-culture that developed and popular at Japan. Since childhood, author was really like comic and Japanese cartoon which famous at that time (1900s). That fondness continuing until author grows up and studying deeper about Japan, include their fashion such as Lolita.

Creation methods that used are data collected from literature study and direct observation. Phenomenological methods are aesthetic, ergonomic, and semiotic. Realization methods that used for all the artworks are tie dye, batik, sulam tapis, and creative decoration technique which inspired from tapestry technique.

The achieved result from this process is eight pieces of art wears dominated in black, red, blue, and purple that dyed from synthetic dyeing. Batik and tie dye applied in many parts of the artwear, such as skirt, pants, sleeve, and blouse. Whereas sulam tapis and creative decoration technique applied as finishing touch to make the artwears looks glamorously.
\end{abstract}

Keywords : Gothic Lolita, artwear, batik, tie dye

\section{INTISARI}

Kumbang tanduk (Oryctes rhinoceros) sebagai inspirasi penciptaan karya seni kinetik kriya kayu memiliki beberapa kelebihan, yaitu keindahan kumbang tanduk dan seni kinetik. Kumbang tanduk memiliki ciri khas berupa tanduk pada kumbang jantan. Bentuk kumbang tanduk mengalami deformasi menjadi karya seni kinetik yang dibuat dengan penuh perhitungan dan dengan mempertimbangkan keindahan gerak yang dihasilkan.

Penciptaan karya tugas akhir ini menerapkan metode tiga-tahap enam-langkah dari SP. Gustami. Karya yang diciptakan adalah karya seni kriya kayu dalam bentuk kumbang tanduk dipadukan dengan seni kinetik. Proses pembuatan karya terdiri dari proses pembuatan desain, pembentukan, finishing, dan evaluasi. Proses penghayatan, penyetaraan antara rasa dan pikiran, dilakukan untuk memberikan spirit dan ruh agar karya dapat memberikan inspirasi, semangat, dan memberikan pesan-pesan kepada orang lain yang melihatnya.

Dari aspek fungsi, karya ini dapat bergerak seperti layaknya kumbang tanduk hidup. Dengan mempertimbangkan nilai estetis, terciptalah enam karya seni ekspresi berwujud tiga dimensi. Karya yang diciptakan menghasilkan karakter baru kumbang tanduk dengan memadukan bentuk-bentuk mekanik mesin seperti roda gigi, stang seher, baut, dan lain-lain. Semua karya terbuat dari kayu dengan tetap memperlihatkan karakter kumbang tanduk.

Kata kunci: kumbang tanduk, deformasi, seni kinetik

*) Dedy Shofianto, Mahasiswa Program Studi S-1 Kriya Seni Jurusan Kriya, Fakultas Seni Rupa, Institut Seni Indonesia Yogyakarta. 


\section{PENDAHULUAN}

\section{Latar Belakang Penciptaan}

Karya seni merupakan hasil ciptaan manusia yang mengungkapkan pengalaman batin atau pangalaman estetik dari seorang seniman, selain itu karya seni diciptakan dalam upaya memenuhi kebutuhan fungsional maupun keindahan. Dalam perjalanan hidup manusia tidak lepas dari tindakan berkesenian, hal tersebut selalu hadir dalam pemenuhan kebutuhan hidup manusia. Aktivitas berkesenian tumbuh dan berkembang seiring dengan latar belakang kehidupan manusia, sehingga seni menjadi berkembang dengan berbagai aliran yang sesuai dengan kehendak, selera dan latar belakang budayanya masing-masing. Aliranaliran seni yang berkembang saat ini diantaranya adalah seni kinetik.

Seni kinetik adalah seni yang melibatkan gerakan, tetapi tidak semua seni yang melibatkan gerakan berarti kinetik. Gerakan itu sendiri sebagai bagian yang integral dengan karyanya (Dharsono Soni Kartika, 2004:118). Dalam istilah seni rupa seni kinetik disebut pula dengan kinetic art, berasal dari bahasa Yunani 'kinesis' atau 'kinetikos', yang berarti 'gerak' digunakan untuk menjelaskan karya-karya yang berhubungan dengan 'gerak' (movement, motion) dalam berbagai bentuknya (http://edwinsgallery.com ). Seni kinetik gerak menjadi salah satu unsur - unsur visual, seperti bentuk dan warna.

Kekinian dalam seni yang disebut sebagai seni kontemporer modern saat ini begitu pesat mempengaruhi perkembangan seni di Indonesia. Kinetic art atau dikenal juga dengan seni kinetik merupakan salah satu media baru dalam bidang seni rupa. Karya yang ditunjukkan merupakan perpaduan antara seni dan teknologi dengan "gerakan" sebagai tema utamanya.

Di Rusia setelah perang dunia I, gagasan tentang seni kinetik muncul pertama kali oleh beberapa seniman: Tatlin, Rodchenko, Naum Gabo, dan Pavsner. Mereka berusaha mengedepankan gagasan tersebut dengan simultan, kemurnian dan kekuatan. Di benua Eropa dan Amerika, kinetik art ini berkembang setelah masa Perang Dunia II. Seni kinetik dianggap sebagai suatu respon artistik para seniman terhadap adanya rasionalitas, ilmu pengetahuan dan teknologi (http://senikinetic.tumblr. com) .

Di Indonesia, era 90-an merupakan saat kemunculan gairah artistik yang timbul sebagai terobosan baru dalam upaya keluar dari batas-batas medium yang pada masa sebelumnya cenderung dominan. Dengan popularitas instalasi dan performans, elemen gerakan muncul dalam tingkat sensibilitas yang berbeda. Utamanya melalui persinggungan dengan budaya dan tradisi semacam seni pertunjukan (teater dan wayang), artefak tradisional, dan juga pada benda-benda keseharian.

Edwin Rahardjo, salah seorang pelopor seni kinetik di Indonesia berusaha mempopulerkan aliran seni tersebut dengan memprakarsai sebuah galeri, yaitu Edwin's Gallery. Di dalamnya, beliau mewadahi aspirasi seni kinetik yang menggabungkan seni tiga dimensi dan prinsip mekanik. Kehadiran karya Edwin Rahardjo seolah menunjukkan bagaimana spektrum praktik seni kinetik di Indonesia mampu membuka kemungkinan adanya kolaborasi yang menarik antara seni dan teknologi. 
Kini, estetika kinetic art telah hadir sebagai suatu metafor dari sebuah narasi, kinerja suatu sistem mekanik, serta motif artistik yang berdiri sendiri. Yang lebih mendasar adalah pentingnya untuk memahami bagaimana ketertarikan mata penikmat karya seni pada sebuah kesan gerakan yang pada dasarnya menjadi wakil bagi sifat-sifat manusia yang timbul secara alamiah.

Penciptaan karya seni kriya kayu sebagaimana ide yang dituangkan oleh penulis, berupa karya seni kriya kayu tiga dimensi dan prinsip mekanik dengan mengambil berbagai elemen dari wujud kumbang tanduk, serta menggabungkan dengan prinsip mekanik yang diinginkan penulis, dari segi ekspresi. Dalam mewujudkan karya tugas akhir ini, banyak mengambil ide visual dari karya-karya seniman yang telah ada sebelumnya dalam batasan sebagai refrensi, diataranya karyakarya Rudi Hendriatno, Edwin Raharjo, Bob Potts yang banyak menonjolkan kinetik untuk ketercapaian ide dalam karyanya. Dalam berbagai hal karya-karya seniman diatas digunakan sebagai rujukan pertimbangan subyektif penulis atas ide penciptaan tugas akhir ini. Dalam tataran teknik karya tugas akhir ini banyak menggunakan teknik dalam disiplin kriya kayu diantaranya teknik kerja bangku, ukir, bubut, scroll saw, dan lain-lain dengan menggabungkan teknik mekanik dan elektonik untuk mempertimbangkan ketercapaian bentuk dan gerak. Penciptaan karya ini lebih mengedepankan ketercapaian ide yang ingin diungkap pada visual karya, di samping keunikan bentuk juga menekankan pada gerakan yang dihasilkan dari teknik perwujudan yang diterapkan.

Karya penciptaan kriya kayu ini sengaja mendeformasi beberapa jenis kumbang tanduk. Hanya kumbang jantan yang bertanduk. Tanduknya digunakan untuk mengupas kulit batang pohon, juga digunakan untuk mempertahankan wilayahnya dari serangga kumbang jantan lain. Secara proporsional, kumbang tanduk adalah hewan terkuat di bumi. Mereka bisa mengangkat hingga 850 kali berat badan mereka sendiri.

Pemaparan seni kinetik dan kumbang tanduk di atas melatar belakangi penulis untuk penciptaan karya pada Tugas Akhir ini dengan memperhitungkan kesesuaian makna, bentuk dan gerak karya, sehingga hasil akhir penciptaan dapat menggambarkan ungkapan estetik dan dapat di apresiasi oleh penikmat dan sesuai dengan konsep dasar penciptaan yang diinginkan.

Proses penciptaan ini juga dapat dilihat dan dipahami melalui skema beriut ini.

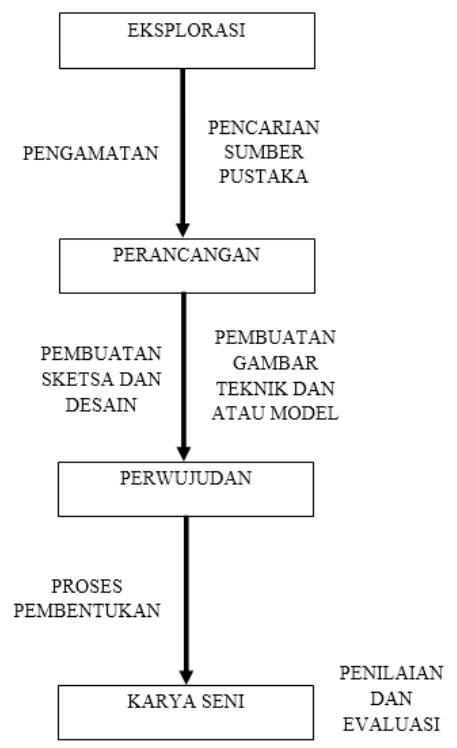




\section{Sumber Penciptaan}

Dalam kehidupan manusia pastilah ada ketertarikan dengan binatang, hal itu yang mendasari dalam penciptaan karya ini. Binatang itu salah satunya adalah kumbang bertanduk. Kumbang bertanduk itu sendiri lebih dari empat juta jenisnya. Kumbang dapat hidup dipegunungan, gurun pasir, lembah yang subur, hutan belantara, padang rumput, dan kolam ikan. Beberapa jenis di antaranya hanya sebesar titik pada huruf i, tetapi ada yang sebesar telapak tangan orang dewasa. Beberapa jenis kumbang berwarna coklat kusam atau hitam, hijau, keemasan, atau biru, dan berkilau seperti batu permata. Kumbang koksi merah yang kecil, kumbang pohon yang besar, dan kunangkunang yang berkelap-kelip, semua adalah jenis kumbang. Kumbang badak adalah adalah salah satu jenis yang oleh para ilmuwan dikelompokan dalam keluarga kumbang bertanduk. Jenis kumbang berbertanduk inilah yang menjadi sumber ide penciptaan (Hidetomo Oda, 1996: 2).

Walaupun berbagai kumbang terlihat sangat berbeda, namun struktur tubuh dan pertumbuhanya serupa. Kumbang bertanduk menjalani metamorfosis sempurna. Kumbang bertanduk adalah serangga malam. Mereka hanya aktif pada malam hari. Mereka tidak suka sinar matahari yang terang. Pada siang hari mereka tidur dibalik dedaunan yang gugur atau akar pohon, dan mulai mencari makan setelah matahai terbenam. Banyak kumbang, terutama sepesies yang besar, adalah penerbang yang kikuk. Beberapa spesies kumbang tanah bahkan sama sekali tidak dapat terbang walaupun mempunyai sayap. Sayap depan kumbang membentuk elitra (pelindung sayap), berbentuk seperti cangkang yang melindungi sayap belakangnya yang tipis dan transparan. Saat terbang, elitra itu dinaikan, namun tetap diam ia bertugas sebagai peluncur yang memberi daya angkat pada kumbang. Sayap belakangnya mengepak dengan cepat, mendorong kedepan.

Dengan tubuh yang berprisai tebal dan tanduk yang seram, kumbang badak terlihat ganas. Hanya kumbang jantan yang bertanduk. Tanduknya digunakan untuk mengupas kulit batang pohon, juga digunakan untuk mempertahankan wilayahnya dari serangga kumbang jantan lain. Secara proporsional, kumbang tanduk adalah hewan terkuat di bumi. Mereka bisa mengangkat hingga 850 kali berat badan mereka sendiri. Kumbang jantan mempertahankan wilayahnya, yaitu suatu pohon karena dua alasan. Pertama, pohon sumber makananya dan yang kedua pohon itu adalah tempat untuk menemukan pasanganya. Kalau kumbang tanduk jantan bertemu dengan kumbang betina, ia akan memberi tanda dengan mengangguk-anggukan tanduknya. Abdomen (Perut) juga bergerak, sehingga sayap depan dan belakangnya yang saling bersentuhan menghasilkan suara. Jika kumbang betina menggapainya, kumbang jantan akan naik ke punggungnya kumbang betina dan mereka kawin.

Setelah mengamati dan melihat bentuk-bentuk kumbang bertanduk, penulis tertarik untuk menuangkanya kedalam karya seni kinetik, dengan mengacu pada keindahan dan cara bertahan hidup kumbang tanduk, seperti 
yang diungkapkan oleh Sudarmaji, "Secara ilmu jiwa yang pertama lahirnya karya seni adalah pengamatan peristiwa. Pengamatan sesungguhnya bukan peristiwa yang lepas dan berdiri sendiri karena seorang mengamati suatu objek maka ada stimulasi (rangsangan) yang selanjutnya seorang akan menangkap suatu makna objek tersebut sesuai dengan pengamatan (Sudarmaji, 1978: 17).

Karya dengan gerakan mekanik telah menguasai beberapa gagasan besar dari Renaissance, termasuk Loenardo da Vinci yang di antara berbagai aktivitasnya, juga mendisain beberapa bentuk karya mekanik untuk hiburan para pangeran dan berbagai festival di kota besar (Gustami, 1991: 87). Seperti di ketahui, Loenardo da Vinci juga mendesain mesin terbang yang pertama. Mimpi untuk terbang seperti seekor burung adalah mimpi yang setua umat manusia itu sendiri. Namun belum ada yang memburunya intensitas, kegigihan, dan komitmen pada riset yang teliti sebagaimana Leonardo da Vinci. Sains tentang penerbanganya melibatkan banyak disiplin mulai dari fluida hingga anatomi manusia, mekanika, anatomi burung, teknik mekanis (Ismanto, 2005: 243).

Seni kinetik biasanya dibagi menjadi dua kategori utama:

- Virtual gerakan: Patung yang tidak benar-benar bergerak

- Nyata Gerakan: Gerakan yang terjadi melalui ilusi atau benar-benar bergerak melalui baik sarana independen atau melihat manipulasi. Kebanyakan seniman Kinetik, namun lebih memilih untuk menggunakan kekuatan alam, yaitu angin, tenaga surya, motor, gravitasi atau magnet untuk daya karyakarya mereka

(http://intlkineticartevent.org/) Adapun ciri-ciri karya Kinetic Art yaitu :

- Adanya susunan dari beberapa gambar dan bentuk dalam ruang yang ditimbulkan oleh adanya gerakan.

- Adanya faktor perubahan. Faktor ini didapatkan dengan menggabungkan beberapa relasi diantara unsur karya yang tetap konstan terhadap setiap gerakan yang variatif, hingga gerakan menunjukkan suatu pola tertentu (https://senikinetic.wordpress.com).

Pengungkapan rasa dan pikiran ini juga berawal dari pengalaman membuat karya yang berkonsep kumbang tanduk kedalam karya kinetik. Pada saat membuat karya berwujud kumbang tanduk tersebut juga pernah dipamerkan di Galeri Seni. Pertama mendapatkan ide dan mulai berpikir tentang bagaimana membuatnya, terpikirkanlah pada bentuk-bentuk seperti itu.

Bentuk-bentuk kumbang tanduk dan gerakan yang dihasilkan dari karya tersebut merangsang untuk menciptakan karya yang lebih berkarakter. Tidak hanya itu, kumbang tanduk juga dideformasi menjadi bentuk-bentuk karya tiga dimensi dengan menggabungkan mekanik utuk menghasilkan karya yang unik dan menarik. Deformasi yang diterapkan yaitu distorsi transformasi, transformasi, dan simplifikasi. Alasan mengapa kumbang tanduk dibentuk dalam wujud berbeda dengan kumbang tanduk sesungguhnya, disebabkan oleh ideide yang ingin diungkapkan. Hal ini juga dipengaruhi oleh alam semesta, karena 
pada dasarnya "alam mempengaruhi semua panca indera, sehingga menimbulkan suatu perasaan estetik (Dick Hartoko, 1995: 19).

Kumbang tanduk tidak dibuat secara realis tetapi diambil bagian-bagian tertentu saja dan dideformasi supaya menghasilkan gerakan dan gerakan itulah yang menjadi pusat perhatian yang melihat karya tersebut nantinya. Untuk menghasilkan gerakan tersebut ada bagian bagian yang integral yaitu bentuk gear, dan dibantu elektrik motor. Pada karya ini gear tidak terbuat dari bahan logam tetapi dari bahan kayu yang dibuat dengan menggunakan mesin scroll saw dan itu membutuhkan ketelitian dan perhitungan yang matang karena jika salah dalam membuat pola gear maka putaran yang dihasilkan tidak senter sehinga karya tersebut tidak akan bergerak.

Dalam pembuat karya seni ini bahan baku pembuatan karya di dominasi dari bahan kayu baik bentuk baut, gear, stang seher dan lain sebagainya. Gerakan yang dihasilkan dari karya tersebut terinspirasi pada gerakan kumbang tanduk itu sendiri dan juga gerakan mekanik mesin mobil. Melalui seni, Kumbang tanduk pun bisa dideformasi sedemikian rupa menjadi sebuah bentuk karya seni kinetik yang tidak ada di alam, tetapi dapat dinikmati secara visual, estetika, gerak ataupun nilai-nilai lain yang terkandung di dalamnya.

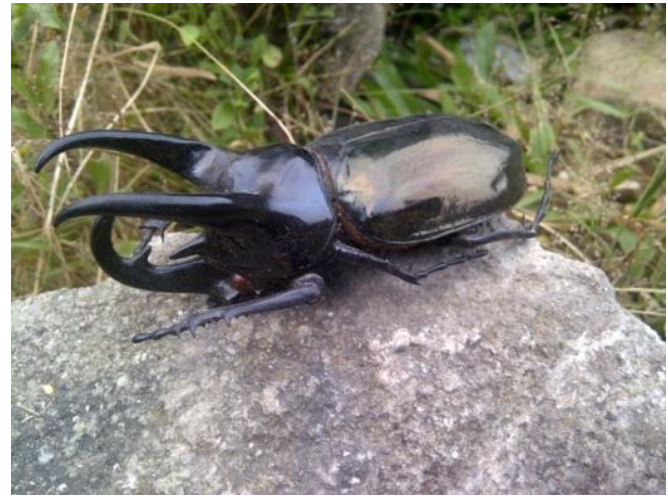

Gambar. 1. Jenis kumbang Tanduk (Chalcosoma atlas) kumbang atlas

(sumber: Dokumentasi pribadi, 3 maret 2014)

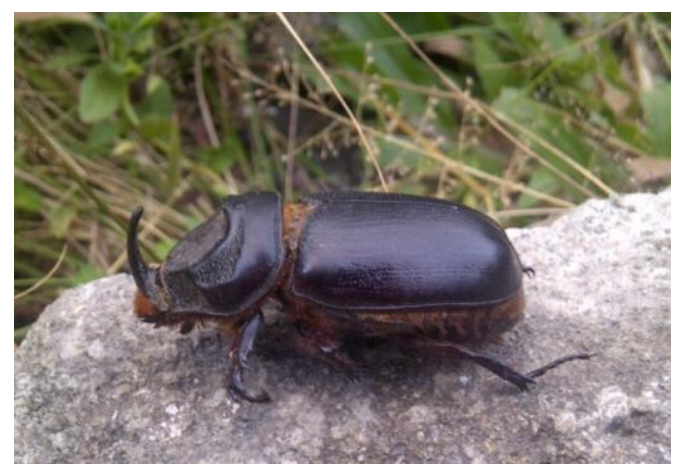

Gambar. 2. Jenis kumbang tanduk (Oryctes nasicornis) kumbang kelapa

(sumber: Dokumentasi pribadi, 3 maret 2014)

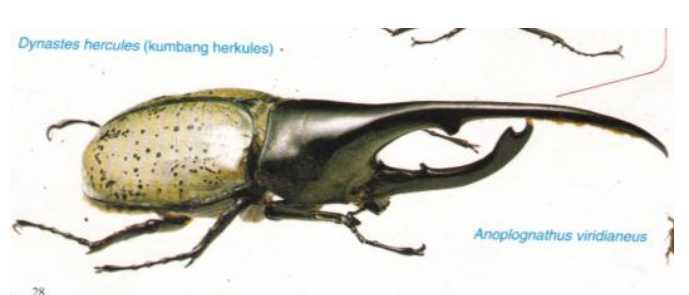

Gambar. 3. Jenis Kumbang (Dynastes Hercules) kumbang herkules (sumber :Hidetomo Oda, Setiadi Handoko, "kumbang". (Jakarta: Elex Media Komputindo kelompok Gramedia, 1996) 3 maret 2014) 


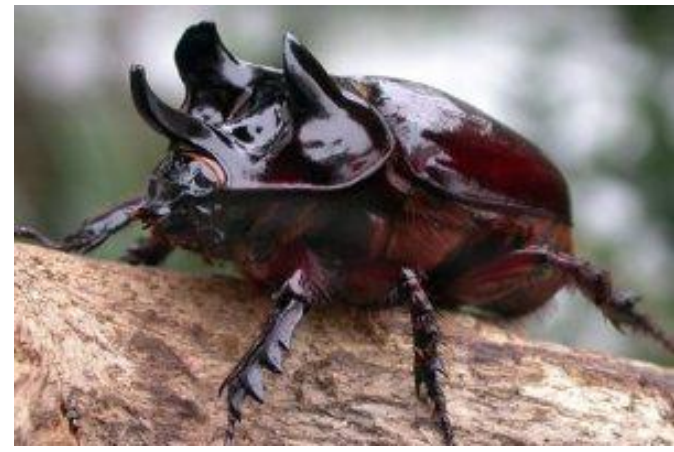

Gambar. 4. Jenis kumbang tanduk (Strategus aloeus) Kumbang banteng

(sumber:

http://adearisandi.wordpress.com/2012/09/02/kum bang-tanduk/. Akses 3 maret 2014)

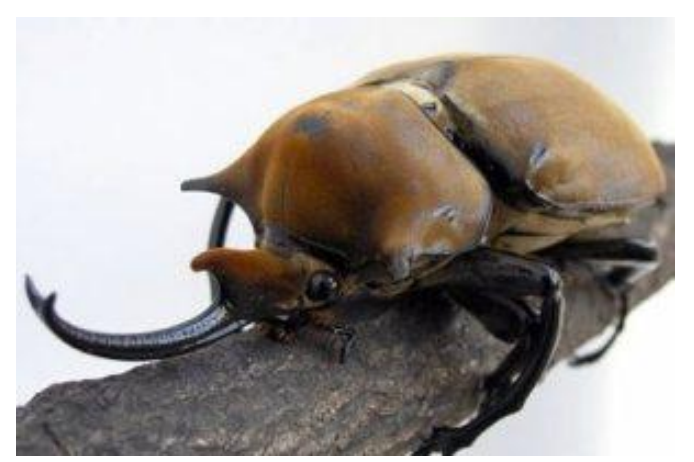

Gambar. 5. Jenis kumbang tanduk (Megasoma elephas) Kumbang Gajah

(sumber:

http://adearisandi.wordpress.com/2012/09/02/kum bang-tanduk/. Akses 3 maret 2014)

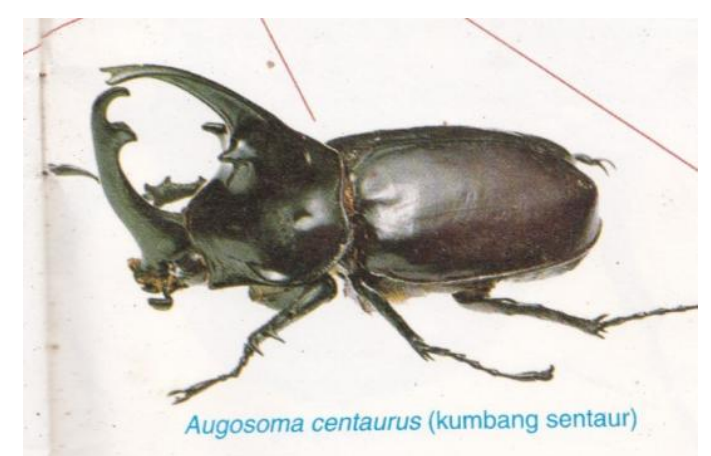

Gambar. 6. Jenis kumbang tanduk (Augosoma Centaur) Kumbang sentaur (sumber: Hidetomo Oda, Setiadi Handoko, "kumbang". (Jakarta: Elex Media Komputindo kelompok Gramedia, 1996) 3 maret 2014)

\section{Rancangan Karya}
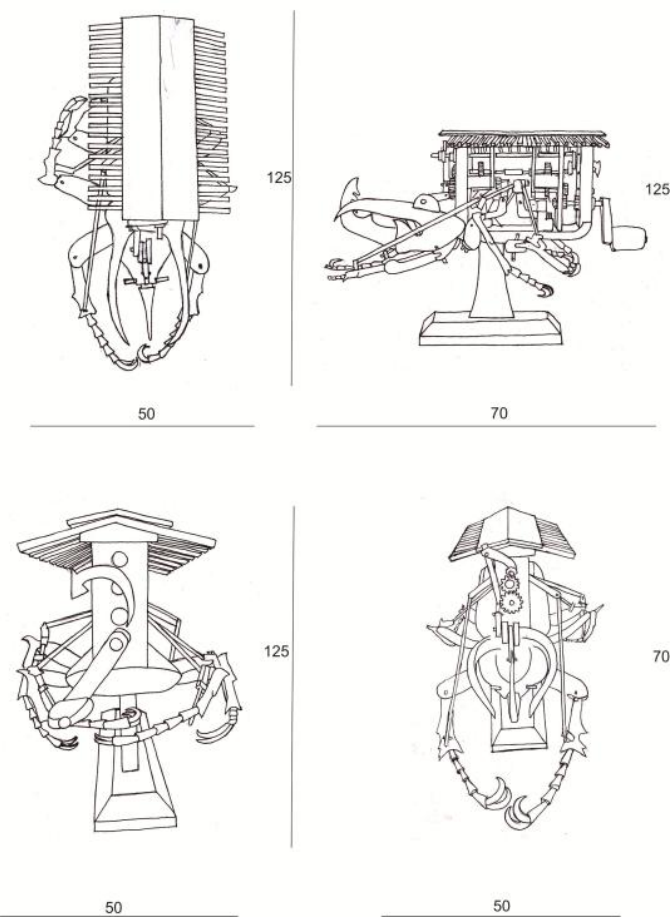

50
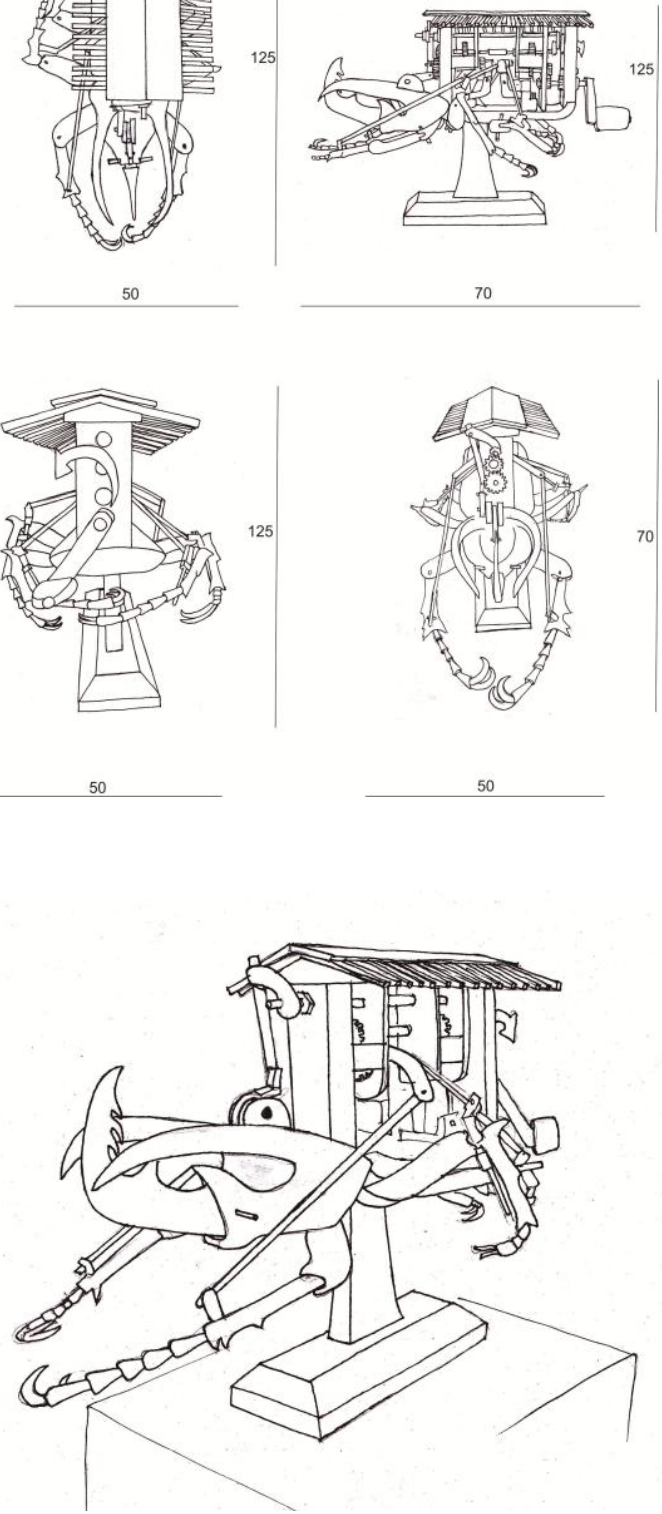

Gambar. 7. Perspektif kerja karya 1

Judul : "Seeking identity"

Ukuran : $70 \mathrm{~cm} \times 50 \mathrm{~cm} \times 125 \mathrm{~cm}$ 

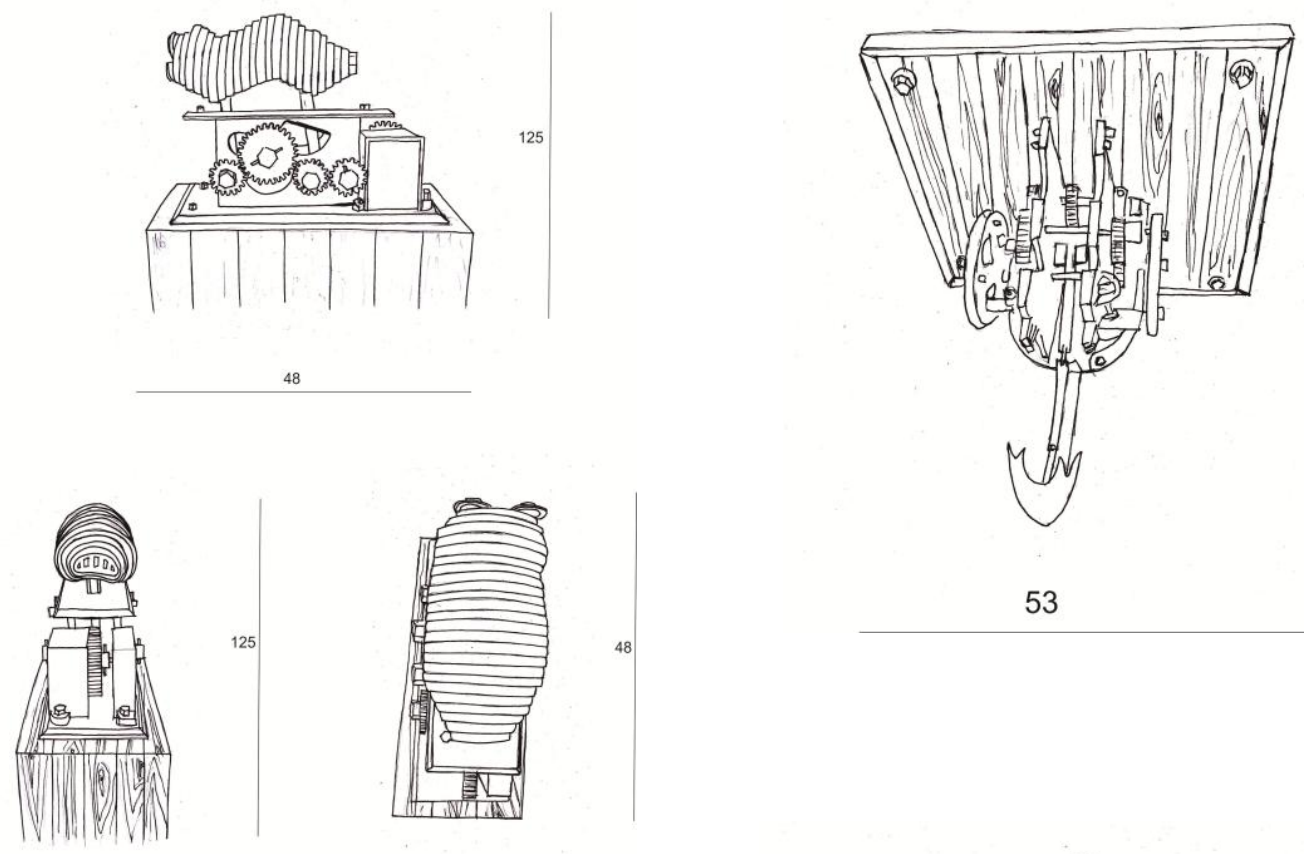

53 53

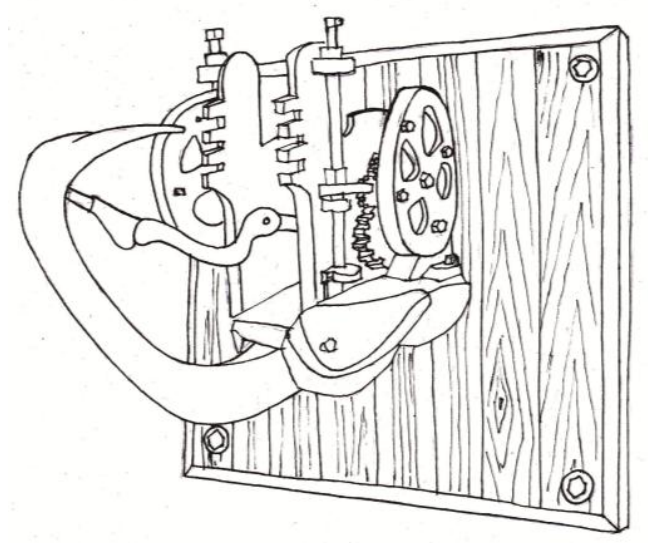

Gambar. 9. Perspektif kerja karya 3 Judul: "Mekanik Kepala Kumbang Tanduk" Ukuran: $53 \mathrm{~cm} \times 53 \mathrm{~cm} \times 53 \mathrm{~cm}$

Gambar. 8. Perspektif kerja karya 2

Judul : "berjuang"

Ukuran : $40 \mathrm{~cm} \times 20 \mathrm{~cm} \times 130 \mathrm{~cm}$ 

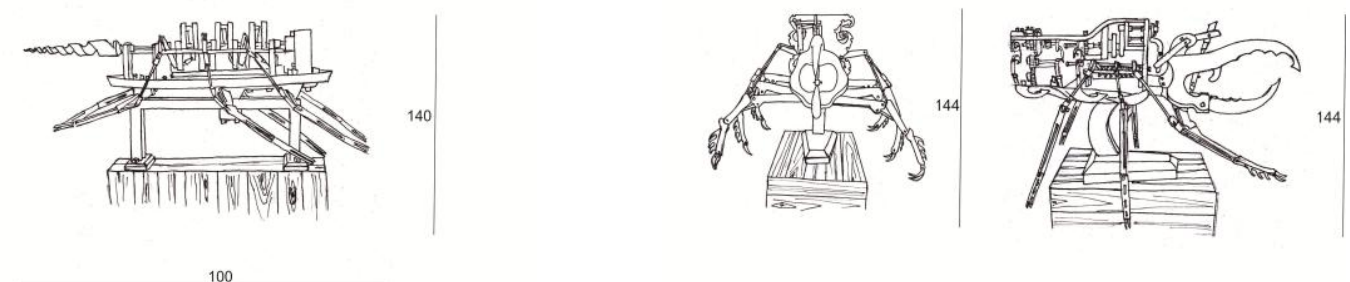

100

120
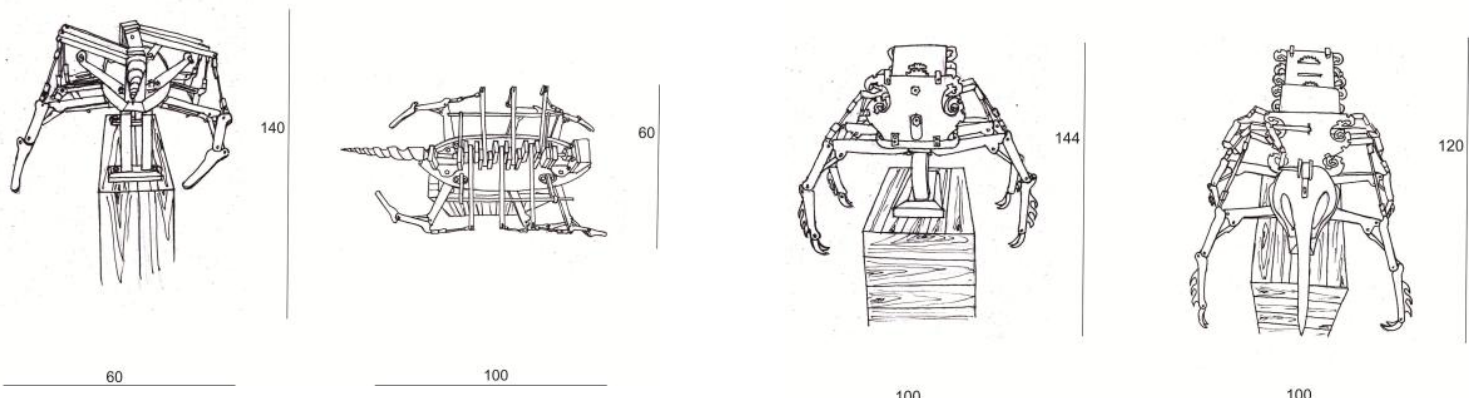

100

100
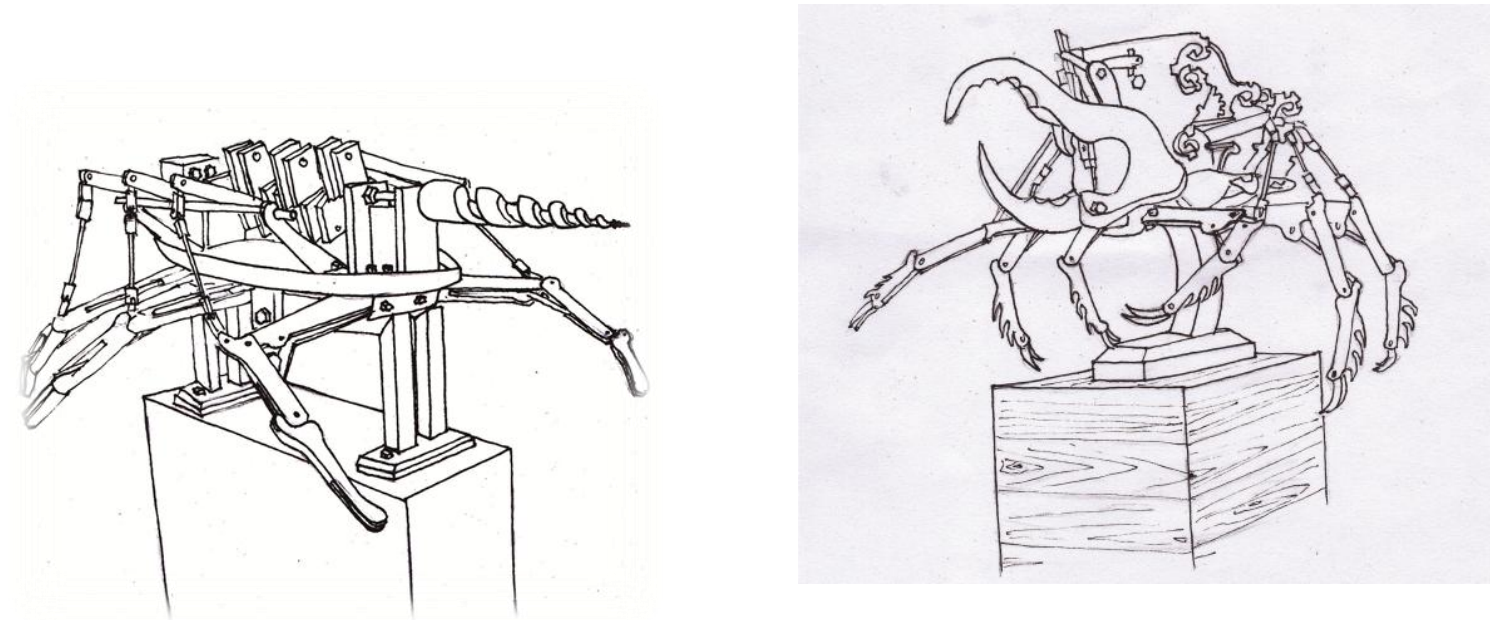

Gambar. 10. Perspektif kerja karya 4

Judul : "Bergerak Menembus Era Globalisasi" Ukuran : $100 \mathrm{~cm} \times 60 \mathrm{~cm} 140 \mathrm{~cm}$

Gambar. 11. Perspektif kerja karya 5

Judul : "Evolution"

Ukuran : $120 \mathrm{~cm} \times 100 \mathrm{~cm} \times 144 \mathrm{~cm}$ 

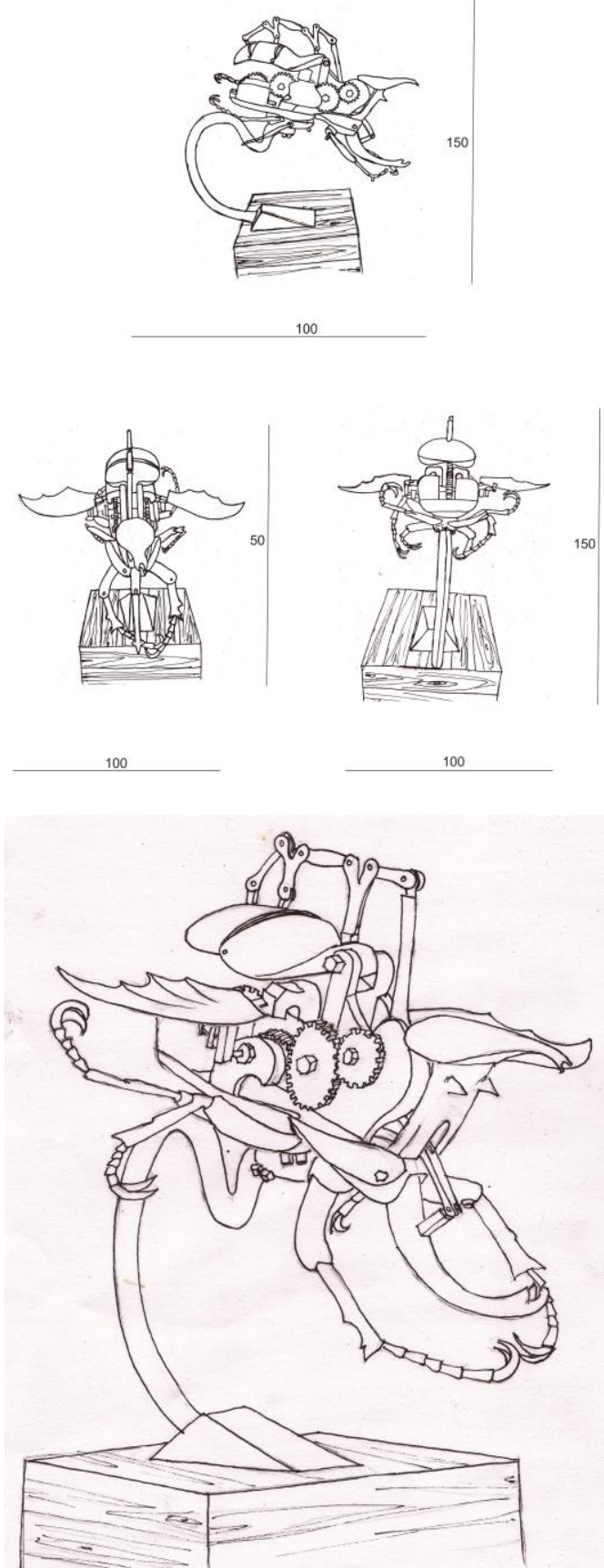

Gambar. 12. Perspektif kerja karya 6

Judul :"Mechanical horn sentaur beetle"

Ukuran $: 100 \mathrm{~cm} \times 100 \mathrm{~cm} \times 150 \mathrm{~cm}$

Berkaitan penciptaan karya seni, tinjauan karya diperlukan untuk melihat dan mengamatii kelebihan dan kekurangan dalam karya yang berkaiatan dengan bahan, teknik, bentuk, gerak serta member ulasan tentang makana yang terkandung dalam karya yang disajikan. Karya yang dihasilkan oleh seniman merupakan ekspresi dan pendeformasian kumbang tanduk kedalam karya seni kinetik.

Kumbang tanduk sering kita jumpai baik dilingkungan alam bebas maupun yang ada di penangkaran, kumbang jantan saja yang hanya memiliki tanduk sedangkan yang betina tidak memiliki tanduk. Dilihat dari bentuk fisik kumbang tanduk memang memiliki karakter menyeramkan dan kuat. Tetapi di Jepang jenis kumbang ini menjadi binatang faforit peliharaan mereka karena kumbang ini dijadikan kumbang aduan. Sedangkan di Indonesia jenis kumbang ini dianggap sebagaian masyarakat kitta sebagai hama pohon kelapa .

Dari banyak kelebihan dan kekurangan yang dimiliki kumbang tanduk, terciptalah karya seni tiga dimensi yang berupa karya seni kinetik. Kinetik adalah seni yang melibatkan gerakan tetapi tidak semua gerakan itu kinetik. Gerakan itulah yang yang utama dalam karya ini. Dari segi bentuk pada karya ini tidak semata hanya memindahkan bentuk dengan sama persis, tetapi lebih ke sebuah pendeformasian dari bentuk kumbang tanduk dan mengutamakan gerakan yang dihasilkan.

Beberapa karya hanya mengambil bagian tertentu dari kumbang tanduk seperti kepala, tanduk dan sayapnya. Ada satu karya yang gerakanya menyerupai gerakan asli kumbang tanduk tetapi bentuk dan gerakanya tidak sama persis dengan kumbang aslinya, karena gerakan yang dihasilkan terlihat kaku dikarenakan gerakan kaku itulah yang membuat menarik.

Konsep utama yang ingin disampaikan pada karya ini adalah tentang Kumbang tanduk kedalam karya seni kinetik. Menjelaskan bahwa gerakan yang dihasilkan dari karya tersebut adalah seni kinetik. 


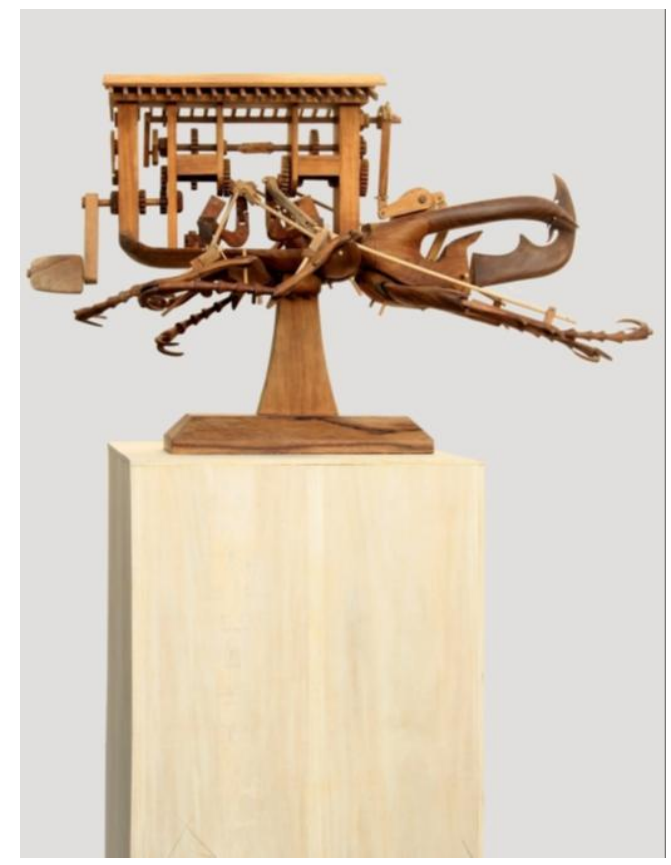

Gambar. 13.

Judul: "Seeking identity"

Bahan: Kayu Jati, kayu gamelina

Teknik: Ukir, kerja bangku,scroll saw, bubut

Ukuran: $70 \mathrm{~cm}$ X $50 \mathrm{~cm} \mathrm{X} 125 \mathrm{~cm}$

Finishing: Sangkling

Tahun pembuatan: 2015

Fotografer: Subekti Subhan Santoso

Karya tugas akhir ini menggunakan media kayu jati sebagai bahan utama, kayu petikemas/packing (pinus) digunakan sebagai bahan pustek karya. Kayu jati dipilih karena memiliki serat yang bagus dan memiliki kualitas yang baik. Dalam karya ini teknik yang digunakan pada proses pengerjaan kayu adalah teknik ukir, kerja bangku, scroll saw, bubut dan lain lain. Sedangkan teknik untuk menghasilkan gerakan menggunakan teknik mekanik.

$$
\text { Visual karya sengaja }
$$

mengkombinasikan beberapa objek sebagai usaha mencapai gagasan penciptaan. Bentuk kumbang tanduk hanya di ambil tanduknya dan kakinya saja bagian tersebut sudah mewakili karakter kumbang tanduk.

Karya ini terispirasi dari kumbang atlas (Chalcosoma atlas), orang jawa sering mengenal dengan sebutan kwawong. Karya ini menggambarkan dan menjelaskan kehidupan manusia dalam sehari-hari, mereka harus belajar mencari jati dirinya sendiri utuk menentukan tujuan yang mereka inginkan tetapi mereka harus memiliki tempat untuk menyerap semua pembelajaran rumah di sini menyimbolkan tempat atau wadah pencarian jati diri.

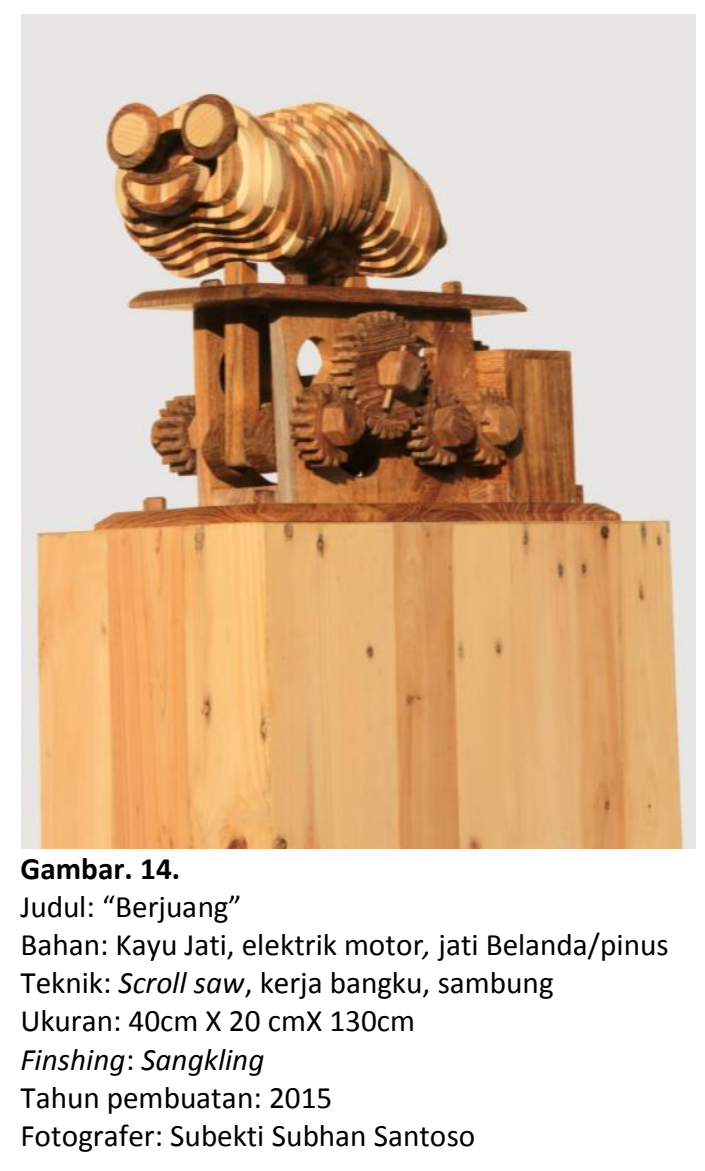

Visual karya ini menggunakan bahan kayu jati, kayu jati Belanda/ pinus. Secara garis besar teknik yang digunakan adalah teknik scroll saw, teknik sambung, kerjabangku.

Karya ini terinspirasi dari larva kumbang tanduk, karya ini menceritakan tentang sebuah perjuangan dalam kehidupan anak bayi. Larva menghabiskan sebagian besar waktunya untuk makan dan tumbuh. Karena cagkangnya masih lunak dan disaat seperti ini larva sulit untuk bertahan hidup karena banyak pemangsa yang sering mengintainya. Seperti halnya anak kecil mereka membutuhkan makan dan minum 
untuk tumbuh dan berkembang menjadi dewasa dan mereka membutuhkan kasih sayang dari seorang ibu untuk memperoleh perlindungan suapaya bisa bertahan hidup.

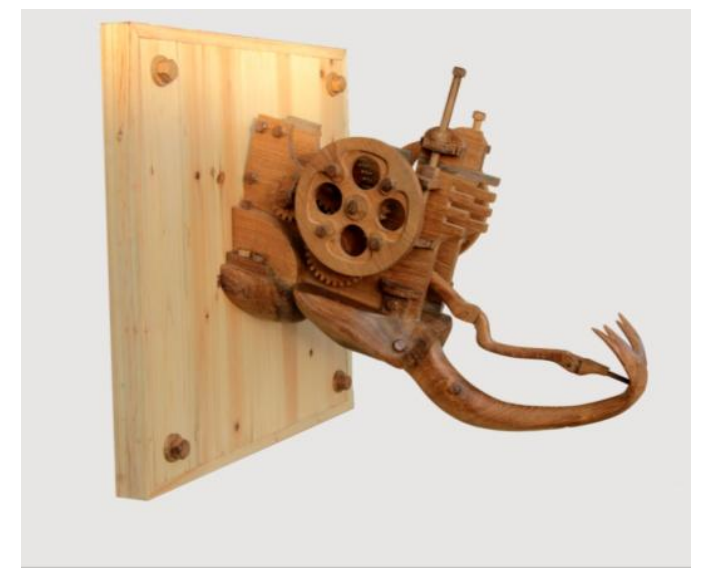

\section{Gambar. 15}

Judul: "Mekanik kepala kumbang tanduk"

Bahan: Kayu Jati, Jati Belanda/pinus, elektrik motor

Teknik: Scroll saw, ukir, kerja bangku, sambung

Ukuran: $53 \mathrm{~cm} \times 53 \mathrm{~cm} \times 53 \mathrm{~cm}$

Finshing: Sangkling

Tahun pembuatan: 2015

Fotografer: Subekti Subhan Santoso

Penciptaan karya tugas akhir ini menggunakan bahan kayu jati, kayu Jati Belanda/pinus. Teknik yang digunakan dalam mengerjakan kayu menggunakan teknik ukir, scroll saw, kerja bangku. Sedangkan teknik untuk menghasilkan gerakan menggunakan teknik mekanik dan dibantu oleh elektrik motor.

Mekanik istilah tersebut biasa disebutkan dalam dunia teknologi, istilah itu sering muncul ketika melihat objek yang menggerakan objek lain. Pada karya ini, bentuk kepala kumbang tanduk dibuat secara deformasi mekanik, tidak menyerupai bentuk aslinya tetapi gerak yang dihasilkan menyerupai gerakan aslinya. Karya ini menghasilkan bunyi tik, tok bunyi itu mewakili kumbang tanduk yang sedang mengelupasi kulit kayu untuk mencari makan.

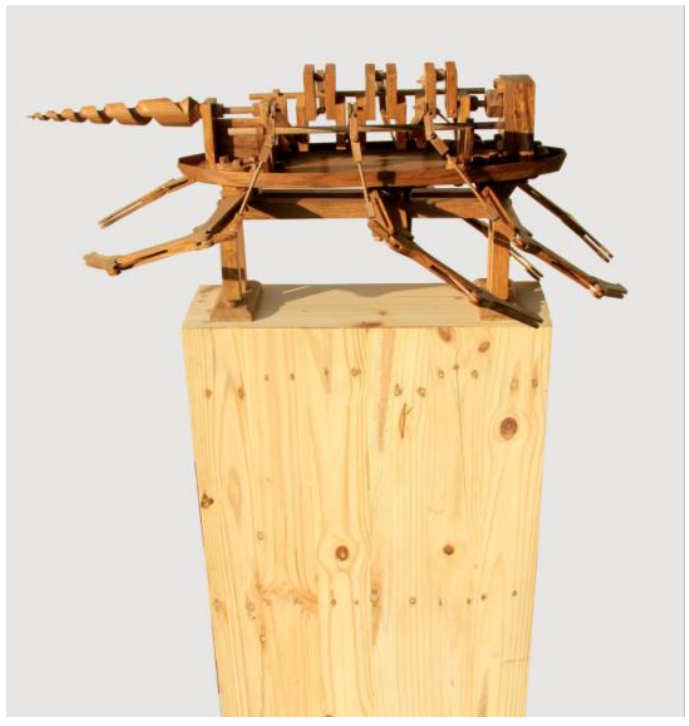

Gambar. 16.

Judul:"Bergerak menembus era globalisasi" Bahan: Kayu Jati, Jati Belanda/pinus, elektrik motor Teknik: Ukir, bubut, scroll saw, kerja bangku Ukuran: $100 \mathrm{~cm} \mathrm{X} 60 \mathrm{~cm}$ X $140 \mathrm{~cm}$

Finishing: Sangkling

Tahun pembuatan: 2015

Fotografer: Subekti Subhan Santoso

Media pada karya ini menggunakan bahan kayu jati, kayu jati Belanda/pinus. Dalam pengerjaan media kayu menggunakan teknik ukir, scroll saw, bubut, kerja bangku. Sedangakan untuk menghasilkan gerakan menggunakan teknik mekanik dibantu dengan elektrik motor. Finishing dalam pengerjaan karya menggunakan teknik sangkling, teknik sangkling adalah teknik finishing dengan cara menggosokan antara kayu dengan karya sehingga hasil yang ditimbulkan terkesan alami .

"Bergerak menembus era globalisasi " merupakan suatu objek yang menandakan sebuah pergerakan menuju perubahan global. Karya ini menceritakan tentang masyarakat saat ini yang mau tidak mau mereka harus bergerak menuju perubahan, gerakan kaki yang dihasilkan itu menyimbolkan pergerakan perubahan. Tetapi sebenarnya masyarakat saat ini belum mamapu menghadapi perubahan tersebut disimbolkan dengan menyerupai perahu nelayan. Sehinggga mau tidak mau 
mereka harus mampu menembus perubahan itu ini disimbolkan gengan gerakan yang dihasilkan mata bor yang berputar berlahan-tapai pasti mereka akan mampu menembus batas yang ada.

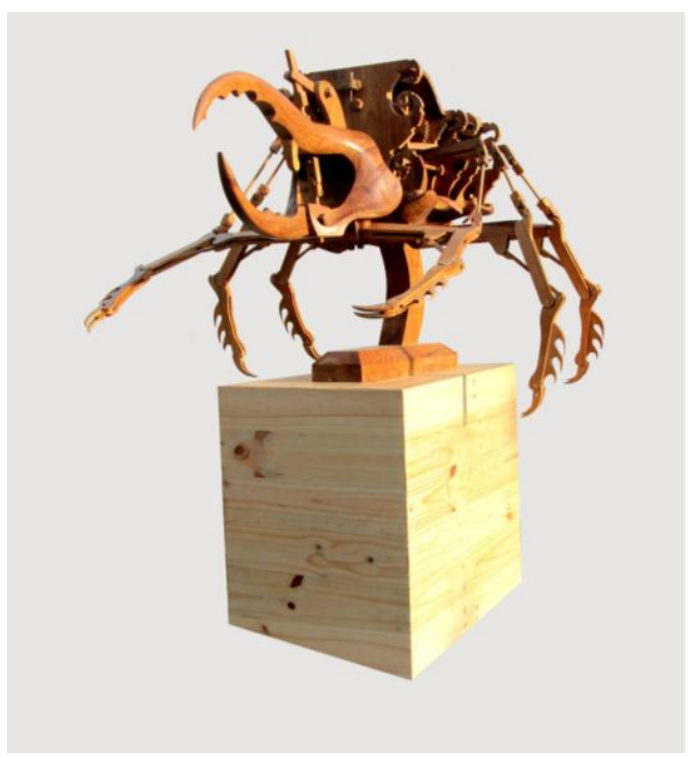

\section{Gambar. 17.}

Judul: "Evolution"

Bahan: Kayu jati, Jati Belanda/Pinus, elektrik motor Teknik: Ukir, bubut, scroll saw, kerja bangku Ukuran: $120 \mathrm{~cm} \times 100 \mathrm{~cm} \times 144 \mathrm{~cm}$

Finishing: Sangkling

Tahun Pembuatan: 2015

Fotografer: Subekti Subhan Santoso

Karya ini terbuat dari bahan kayu jati, jenis karya ini adalah karya tiga dimensi yang menggabungkan antara seni tiga dimensi dan prinsip mekanik yang sering disebut dengan kinetik art. Karena karya ini, gerak menjadi salah satu usur-usur visual seperti bentuk dan warna. Dalam pengerjaan karya ini menggunakan teknik pahat, scroll saw, bubut, mekanik, elektronik dan lain-lain. Finishing dalam pengerjaan karya menggunakan teknik sangkling, teknik sangkling adalah teknik finishing dengan cara menggosok antara kayu dengan karya sehingga hasil yang ditimbulkan terkesan alami.

"Evolution" adalah proses di mana organisme berubah dari waktu ke waktu sebagai akibat dari perubahan sifat fisik atau perilaku diwariskan. Pada karya seni ini, kumbang tanduk jenis Kumbang Herkules (Dynastes Hercules) menjadi salah satu bentuk objek karya seni kinetik. Evolution disini diartikan dengan perkembangan seni rupa global saat ini yaitu menggabungkan atara seni dan teknologi. Perkembangan seni saat ini seakan-akan bergerak kearah kedua hal tersebut sehingga menghasilkan karya yang mampu menjawab perkembangan seni rupa Indonesia pada perkembangan seni rupa global.

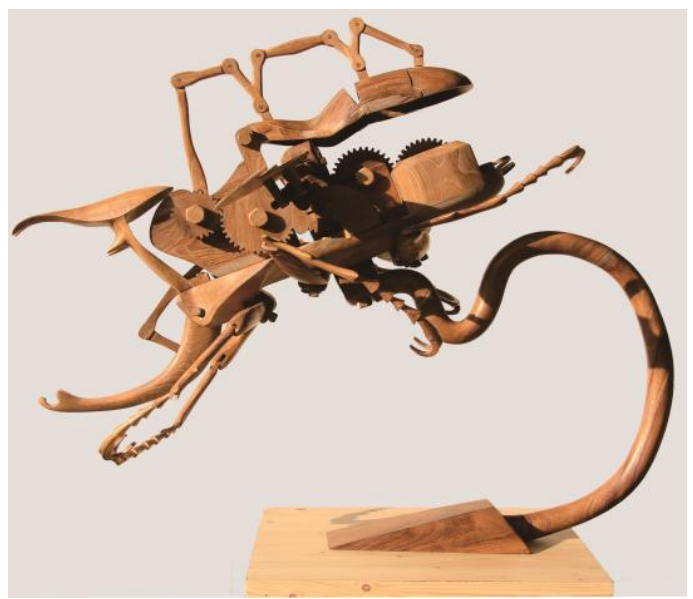

Gambar. 18.

Judul: "Mechanical horn sentaur beetle" Bahan: Kayu jati, Jati Belanda/pinus, elektrik motor Teknik: Ukir, bubut, kerja bangku, scroll saw Ukuran: $100 \mathrm{~cm} \times 100 \mathrm{~cm} \times 150 \mathrm{~cm}$

Finishing: Sangkling

Tahun pembuatan: 2015

Fotografer: Subekti Subhan Santoso

Media pada karya ini menggunakan kayu jati, bahan ini dipilih karena kayu jati memiliki serat yang bagus dan kayu jati memiliki tekstur serat yang jelas terlihat dengan bentuk meliuk-liuk. Nama ilmiah dari kayu ini adalah Tectona grandis. Permukaan kayu jati berwarna cokelat. Kayu ini termasuk kayu yang memiliki kekerasan sedang. Kayu jati pada karya ini menjadi material utama dan dibantu dengan elektrik motor sebagai penggeraknya karya. Teknik yang digunakan pada proses pengerjaan ini menggunakan 
teknik ukir, kerja bangku, bubut, scroll saw, mekanik dan elektonik. Finishing dalam pengerjaan karya menggunakan teknik sangkling, teknik sangkling adalah teknik finishing dengan cara menggosok antara kayu dengan karya sehingga hasil yang ditimbulkan terkesan alami.

Visual karya ini sengaja mendeformasi bentuk kumbang tanduk jenis sentaur kedalam bentuk mekanik. Mekanik berarti ilmu pengetahuan yang mempelajari gerakan suatu benda serta efek gaya dalam gerakan itu. Seperti halnya dengan karya ini, karya ini sengaja mengambil gerakan asli kumbang tanduk dengan menggabungkan gerakan mekanik supaya terlihat ada kesan yang berbeda dari kumbang yang sebenarnya karena yang mekanik itu memiliki nilai estetik.

\section{PENUTUP}

Proses penciptaan di atas merupakan proses yang dilakukan sebagai tahap penyelesaian tugas akhir. Tahap penciptaan yang dilakukan mulai dari eksplorasi ide. Ide utama dari karya yang dibuat adalah bentuk Kumbang tanduk kedalam karya seni kinetik. Penuangan ide ke dalam bentuk sketsa dan desain menjadi pengantar terwujudnya ide menjadi sebuah karya seni. Perwujudan adalah tahap paling berpengaruh atas terciptanya sebuah karya seni yang memiliki nilai tanda dan jaringan makna.

Penciptaan ini menghasilkan enam karya seni kriya tiga dimensi. Menghasilkan karakter baru dari kumbang tanduk, sebagai hasil dari proses deformasi, yaitu berupa kumbang tanduk kedalam karya seni kinetik dengan meperhitungkan gerakan yang dihasilkan.

Berdasarkan apa yang telah dilakukan, terjadi beberapa kendala yang sedikitnya mempengaruhi proses dari penciptaan. Mulai dari kendala teknis yaitu dalam proses finishing proses ini menggunakan teknik sangkling, sehinggga perlu bongkar pasang karya yang sudah biasa bergerak harus dibongkar terlebih dahulu untuk proses penyangklingan kemudian baru bias dirangkai menjadi satu kesatuan , karena kerumitan-kerumitan bagian yang disangkling.

Dengan terciptannya karya-karya ini, semoga dapa menjadi bahan kajian, diskusi, ataupun kritikan. Dapat juga memperkaya khasanah seni kriya dalam pendidikan seni.

\section{DAFTAR PUSTAKA}

Gustami,SP., Seni Sebagai Ujud dan Gagasan, Yogyakarta: Fakultas Seni Rupa dan Desain Institut Seni Indonesia Yogyakarta, 1991.

,Trilogi Keseimbangan", Ide Dasar Penciptaan Seni Kriya Untaian Metodelogis, dalam Jurnal Dewa Ruci, Volume 4, No. 1, ISI, Surakarta, 2006.

"Proses Penciptaan Seni Kriya: Untaian Metodologis", Program Pascasarjana S2 Penciptaan Dan Pengkajian Seni ISI Yogyakarta, 2004.

Ismanto,An.Sains Leonardo,"menguak kecerdasan terbesar Masa Renaisans" Yogyakarta: Jalasutra Anggota IKAPI,2005.

Kartika, Dharsono Sony, Seni Rupa Modern, Bandung: Rekayasa Sains, 2004.

Oda Hidetomo, Handoko Setiadi, Kumbang, Jakarta: Elek Media Komputindo Kelompik Gramedia, 1996.

SP., Soedarso, Tinjauan Seni: Sebuah Pengantar untuk Apresiasi Seni, Yogyakarta: Saku Dayar Sana, 1990. 
Sudarmaji,Dasar-dasar Kritik Seni Rupa, Dinas Museum dan Sejarah, Jakarta,1979.

Hartoko, Dick, Manusia dan Seni, Yogyakarta: Kanisisius, 1995.

Susanto, Mikke, Diksi Rupa: Kumpulan Istilah Dan Gerakan Seni Rupa, Yogyakarta: Dicti Art Lab dan Djagad Art House, 2011.

\section{WEBTOGRAFI}

http://edwinsgallery.com/kinetik_perkemb angan.php akses 13 Januari 2014 jam 22:40 WIB.

http://senikinetic.tumblr.com/.akses 22 juni 2015 jam 10:26 WIB.

http://translate.google.co.id/translate?hl=i $\mathrm{d} \& s \mathrm{l}=$ en\&u=http://intlkineticartevent.org/ \%3Fpage_id\%3D107\&prev=search akses 25 juni 2015 jam 8:45 WIB.

https://senikinetic.wordpress.com/.akses 25 juni 2015 jam 8:45 WIB.

http://adearisandi.wordpress.com/2012/0 9/02/kumbang-tanduk/. Akses 3 maret 2014 WIB.

http://kdri.web.id/content/kumbangtanduk. akses 2maret 2014.

http://toyrobot.sulit.com.ph. Akses 2 maret 2014.

http://baltyra.com/2011/09/15/yang-unikdi-saat-musim-panas/.akses 2 maret 2014.

http://www.lintas.me/fun/unikaneh/kamkus.blogspot.com/inilah-robotraksasa-kumbang-tanduk-hasil-karyaorang-jepang. akses 3 maret 2014.

http://businesslounge.co.id/2014/10/30/s ekilas-karya-karya-menarik-dalampameran-trienalversi/, akses 24 juni 2015.

http://indoartnow.com/artists/edwinrahardjo, akses 24 juni 2015.

http://edwinsgallery.com/artworks_detail. php?idart=159\&id=MTk5 24 juni 2015

http://krjogja.com/read/222287/pameranperdana-gajah-gallery.kr .12 februari 2015. 